\title{
IMPACT OF SENSOR READINGS OF GRAIN MASS YIELD ON COMBINE SPEED
}

\author{
Vojislav Simonovic, Dragan Markovic, Ivana Markovic, Snezana Kirin
}

Original scientific paper

The paper analyzes the impact of sensor readings of dry grain mass yield of wheat, barley and rapeseed on combine speed during harvesting on three plots. The combine was fitted with site-specific yield monitoring sensors. This paper displays detailed tables of statistical procedure carried out for wheat in the analysis of combine speed, whereas final results for barley and rapeseed are itemized. After harvest, the three plots were divided into three groups each according to yield levels: low, medium and high, respectively. On the rapeseed plot, the Kruskal-Wallis $\mathrm{H}$ test did not reveal statistically significant difference in combine speed between the plot zones that belong to different yield-level groups, $\chi^{2}(2, N=2187)=4,570, p=0,102$. On the basis of mean values for group ranks, the highest combine speed on wheat and barley plots has been found in the medium-yield-level group. Therefore, subsequent analysis of differences was conducted between the groups using Mann-Whitney U test. Combine speed during wheat harvest did not differ significantly in the low- and high-yield-level zones of the plot, $Z=-1,213$ and $N=3453, p=0,225$, while comparison between speeds within the medium-yield-level group to the other two groups exhibited statistically significant difference, effect size being approx. 0,1. During barley harvest, combine speeds differ statistically significantly when all three groups are compared for low and high impact according to Cohen's criterion based on effect size.

Keywords: combine speed; grain mass yield; sensor

Utjecaj masenog prinosa izmjerenog senzorima na brzinu kombajna

Izvorni znanstveni članak

Analiziran je utjecaj prinosa suhog zrna pšenice, ječma i uljane repice očitanih senzorom na brzinu gibanja kombajna tijekom žetve na tri parcele. Kombajn je bio opremljen senzorima za nadzor lokacijski specifičnog prinosa. U ovom radu su tablicama detaljno prikazane statističke procedure analize brzine za pšenicu, dok su krajnji rezultati istraživanja za ječam i uljanu repicu taksativno navedeni. Sve tri parcele su naknadno nakon obavljene žetve podijeljene u po tri skupine prema razini prinosa, i to na mali, srednji i veliki prinos, retrospektivno. Na parceli uljane repice Kruskal-Wallis $\mathrm{H}$ test nije otkrio statistički značajnu razliku brzine gibanja kombajna u dijelovima parcele koji pripadaju različitim skupinama prinosa, $\chi^{2}(2, N=2187)=4,570, p=$ 0,102 . Na parcelama s pšenicom i ječmom otkriveno je na temelju srednjih vrijednosti rangova grupa da je brzina najveća u skupini sa srednjim prinosom, pa se pristupilo naknadnoj analizi razlike među skupinama pomoću Mann-Whitney U test. Brzina gibanja kombajna tijekom žetve pšenice nije se razlikovala statistički značajno u dijelovima parcele s malim i velikim prinosom, $Z=-1,213$ i $N=3453, p=0,225$, dok se prilikom usporedbe brzina unutar srednje grupe prinosa s preostale dvije grupe razlikovala statistički značajno, i s veličinom učinka oko 0,1 . Tijekom žetve ječma, brzina kombajna statistički se značajno razlikuje kada se uspoređuju sve tri skupine za niske i visoke utjecaje prema Cohen-ovom kriteriju na temelju veličine učinka.

Ključne riječi: brzina kombajna; maseni prinos zrna; senzor

\section{Introduction}

Reported accuracy of continuous yield monitoring depends on the type and brand of yield monitor, calibration regime, flow rate and conditions at harvest. Accuracy ranges from 93 to $99,5 \%[1,2,3]$. Gradual and sudden speed changes affect the accuracy of yield measurements. Arslan and Colvin [2] showed that average error rates at a constant speed were $3 \%$, but varying speed between 8 and $11 \mathrm{~km} / \mathrm{h}$ increased the average error to $5,2 \%$. When combine speed varied gradually, depending on yield variation, the measurement error almost doubled. Larger errors are observed when ground speed changes abruptly [4].

This paper presents the results of investigations carried out throughout the harvest of wheat (Triticum aestivum), barley (Hordeum vulgare) and rapeseed (Brasica napus) on three plots. Note that harvest time, June-July 2014, was ideal for research activities of this type and concept, because yield level in experimental plots was markedly non-uniform due to high precipitation amounts that caused lodging of stems during vegetative growth and harvest, as well as due to the invasion of rodents since time immemorial resulting in crop stand thinning. Apart from non-uniform yield levels, the consequence of both events was a reduced yield level compared to average level recordings on these plots in previous years. The circumstances mentioned are related to experimental plots planted with wheat and barley, whereas rapeseed stand was very uniform and yield level was above average.

\section{Material and methods}

Yield monitoring in combine harvesters is a cornerstone of precision agriculture. It relies on measurement of the grain flow through the harvesting equipment. Typical mechanisms that have been implemented to monitor grain flow through a combine can be grouped into volumetric flow sensors, mass flow sensors, and indirect measurement devices. Among them, impact-type mass flow sensors are widely used in many state-of-the-art yield monitors [5]. They consist of an impact plate and a force transducer that converts the net time-averaged impact force into a voltage signal. This type of structure is so simple that impact-type sensors can be easily mounted on combine harvesters and risk of causing an obstruction of the normal threshing process, even when the sensors are damaged, is minimized [6].

Combine harvester used in this investigation was equipped with a header, cutting width $6 \mathrm{~m}$. A grain mass flow sensor is mounted on the top of the clean grain auger, and grain moisture measurement sensor is positioned in the middle of the clean grain auger, Fig. 1. The grain mass flow sensor measures the impact force with which the grain expelled from the elevator paddles strikes against the impact plate. On the basis of this force, as well as known header width, speed of motion and grain auger speed, moisture content, dry grain mass yield was 
calculated. The effect of combine vibrations was eliminated by prior mass flow sensor calibration. Grain moisture sensor was also calibrated ahead.

a)

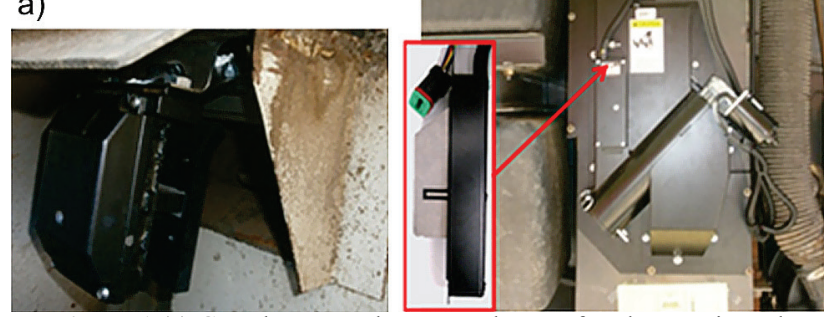

Figure 1 (a) Gape between elevator and auger for clean grain and impact plate of mass flow sensor with module (view grom grain tank) and (b) grain moisture sensor

The system for measuring grain yield is adjusted to successively record data at 2 -second intervals. This was a constant time interval of measuring. The only parameter that changed was the distance travelled during that time, depending on the combine speed and was also recorded at 2 -second intervals. The recording of measurements at $1 \div 3$ second intervals generates large datasets, even for small fields [4].

Early studies focused on minimising the travel time delay between the crop being cut and measured at the yield monitor. Time offsets have been applied so that measurements at the monitor match the actual harvest position. Actual delay times vary between the type and model of harvester, yield monitor and GPS receiver $[7,8$, 9] and within fields due to crop conditions [7]. Data time shift used in this paper amounted to 10 seconds. Various factors such as combine separator design and settings and monitoring systems can affect the data gathering process so that the time shift should be adjusted. Without this adjustment, the grain flow and moisture values cannot be properly coordinated with location and area information to deliver data that accurately represents that location [1].

The research issue in this paper seeks to examine how combine harvester speed changes depending of yield level arranged into three groups (ranks). By classifying yield level into three groups and taking into account a very close interconnection between the harvesting speed and productivity, the plots were categorized as low-, mediumand high-fertile, and harvests as low-, medium- and highproductive. In order to examine mentioned impact, the Kruskal-Wallis $\mathrm{H}$ test is deployed. It compares the results of any continuous variable with three or more groups and tests the null hypothesis that $k$ independent samples are chosen from the same population or identical populations with the same median. The only assumptions of this nonparametric test are that the observed variables have continuous distribution and are measured with the ordinal measurement scale. It is implied that this study also includes operator's personal habits that directly influence the combine harvester speed of motion. This factor, however, was reduced to the minimum, because the combine was operated by an experienced operator during the entire investigation. It employed one categoryindependent variable with three categories, (sensor readings of dry grain mass yield level) and one continuous dependent variable (combine speed).

Since the investigation was carried out based on dry grain mass flow, it requires site-specific measurements of grain moisture content. In this paper, statistical methods are used to check the statement that maintaining a constant ground speed during harvest improves yield measurement [10].

Many studies [11, 12, 13] have found that non-normal yield distributions are due to a high proportion of low yield measurements. Data for the observed three plots in this paper did not undergo normal distribution either, so that nonparametric methods were used for the analysis and comparison between groups.

If median for the $j^{\text {th }}$ group is designated with $\theta_{j}$, the null hypothesis can be written as

$H_{o}: \theta_{1}=\theta_{2}=\cdots=\theta_{k}$

and the alternative hypothesis is:

$H_{1}: \theta_{i} \neq \theta_{j}$

for any $i$ and $j$.

In performing the Kruskal-Wallis $\mathrm{H}$ test each observation is substituted by a particular rank. Namely, all observations (from all $k$ samples) are merged into a single group and ranked into a single series, so that the lowest value is assigned rank 1 . Thereafter, the sum of ranks as well as the average rank is calculated for each of the columns. If samples are chosen from the same or identical populations, average ranks are expected to be approximately the same for all groups and columns, respectively. The Kruskal-Wallis $\mathrm{H}$ test is statistically calculated as follows [14]:

$H=\left[\frac{12}{N(N-1)} \sum_{j=1}^{k} \frac{R_{j}^{2}}{n_{j}}\right]-3(N+1)$,

where

$k$ - number of samples,

$N$ - total number of observations in all samples,

$n_{j}-$ number of observations in the $j^{\text {th }}$ column,

$R_{j}-$ sum of ranks in the $j^{\text {th }}$ group.

If the null hypothesis is true, then the $\mathrm{H}$ statistic has chi-square distribution with $d f=k-1$ degrees of freedom, provided the size of each $k$ sample is not too small (that it is $>5$ ).

\section{Results and discussion}

The impact of sensor readings of dry grain mass yield on combine speed was investigated on an experimental plot after measuring devices for yield measurements were calibrated. In order to conduct the investigation procedure according to the Kruskal-Wallis $\mathrm{H}$ test requirements, the continuous variable dry grain mass yield was categorized 
for this plot by dividing it into the following groups (ranks):

- $\quad$ low yield level $(\leq 3650 \mathrm{t} / \mathrm{ha})$,

- medium yield level $(3651 \div 4400 \mathrm{t} / \mathrm{ha})$,

- $\quad$ high yield level ( $\geq 4401 \mathrm{t} / \mathrm{ha})$.

On the basis of this categorization, using Tab. 1, it is noticeable that the number of samples is evenly distributed within each group. Yield map of dry wheat grain for this plot, according to presented categories, is given in Fig. 2. The thus grouped dry grain yield can be used to define organizational zones of the investigated part of the plot.

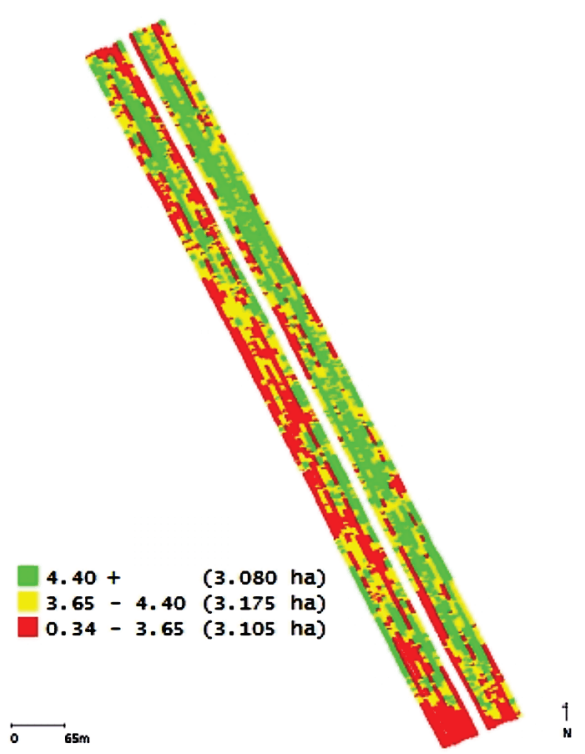

Figure 2 Representation of site-specific sensor readings of dry wheat grain mass yield in $\mathrm{t} / \mathrm{ha}$

The results obtained for wheat in the analysis of yield impact on combine speed using the appropriate program procedures in the SPSS Statistic 21 program package are given in Tabs. 1 and 2.

Table 1 Average ranks for wheat

\begin{tabular}{|c|c|c|c|c|}
\hline & $\begin{array}{l}\text { Mass yield dry } \\
\text { grain (binned) }\end{array}$ & $N$ & Mean rank & Median \\
\hline \multirow{4}{*}{ 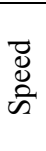 } & $<=3,650$ & 1728 & 2522,08 & 5,3900 \\
\hline & $3,651-4,400$ & 1742 & 2828,24 & 5,5100 \\
\hline & $4,401+$ & 1725 & 2441,54 & 5,3700 \\
\hline & Total & 5195 & & 5,4200 \\
\hline
\end{tabular}

Table 2 Kruskal-Wallis $H$ test results for wheat

\begin{tabular}{|l|r|}
\hline \multicolumn{1}{|c|}{ Grouping variable: yield mass(dry) (binned) } & \multicolumn{1}{c|}{ Speed } \\
\hline Chi-Square & 64,256 \\
\hline$d f$ & 2 \\
\hline Asymp. Sig. & .000 \\
\hline
\end{tabular}

The Kruskal-Wallis $\mathrm{H}$ test for wheat has revealed statistically significant difference in combine speeds between plot zones belonging to different yield level groups (group 1 or low-yield-level group, $N=1728$ : to $3,65 \mathrm{t} / \mathrm{ha}$; group 2 or medium-yield-level group, $N=$ 1742: $3,651 \div 4,400 \mathrm{t} / \mathrm{ha}$; group 3 or high-yield-level group, $N=1725$ : above $4,4 \mathrm{t} / \mathrm{ha}), \chi^{2}(2, N=5195)=$ $64,256, p=0,000$. The medium-yield-level group is characterized by the median $\left(M_{d}=5,51\right)$ higher than in the other two yield-level groups, whose median amounts to $M_{d}=5,39$ for low-yield-level group and $M_{d}=5,37$ for high-yield-level group, respectively. The significance level is 0,000 for mentioned results. This is lower than the alpha level of 0,005 , so it can be deduced that the null hypothesis is rejected, i.e., there is a difference between combine speeds along plot zones with different yield levels. A survey of mean (average) values for group ranks indicates that the highest speed is found in the mediumyield-level group, whereas combine speed is pretty uniform in the other two groups.

The same procedure was applied to the analysis of yield level impact on combine speed for barley and rapeseed. The summary of the analysis is as follows.

The Kruskal-Wallis $\mathrm{H}$ test for barley has revealed statistically significant difference in combine speeds between plot zones that belong to different yield-level groups (group 1 or low-yield-level group, $N=698$ : to 3,09 t/ha; group 2 or medium-yield-level group, $N=697$ : $3,091 \div 5,340 \mathrm{t} /$ ha; group 3 or high-yield-level group, $N=$ 695: above 5,34 t/ha), $\chi^{2}(2, N=2090)=203,569, \mathrm{p}=0,000$. The medium-yield-level group is characterized by the highest median $\left(M_{d}=4,59\right)$ compared to the other two groups, whose median is significantly lower amounting to $M_{d}=4,02$ for the high-yield-level group and $M_{d}=3,87$ for the low-yield-level group, respectively. A survey of mean (average) values for group ranks indicates that the highest speed is found in the medium-yield-level group, whereas in the low- and medium-yield-level zones the combine speed is reduced. Chi-square is significantly higher than for the case of analyzed wheat plot, indicating even greater oscillations in combine speed in the barley plot.

The Kruskal-Wallis $\mathrm{H}$ test for rapeseed did not demonstrate statistically significant difference in combine speeds between plot zones of different yield-level groups (group 1 or low-yield-level group, $N=731$ : to 2,15 t/ha; group 2 or medium-yield-level group, $N=726: 2,151 \div$ 2,9 t/ha; group 3 or high-yield-level group, $N=730$ :above $2,901 \mathrm{t} / \mathrm{ha}), \chi^{2}(2, N=2187)=4,570, p=0,102$. The medium-yield-level group is characterized by the lowest median $\left(M_{d}=3,765\right)$ compared to the other two groups, whose median is slightly higher: $M_{d}=3,81$ for the highyield-level group and $M_{d}=3,80$ for the low-yield-level group, respectively. In mentioned results, the significance level is 0,102 . This is the only experiment where the significance is higher than alpha level amounting to 0,005 , therefore the null hypothesis is accepted, i.e., there is no difference between combine speeds for rapeseed plot zones with different yield-level groups.

For the case of wheat and barley analysis, statistically significant results of the Kuskal-Wallis $H$ test were obtained, but it is still unknown which groups differ statistically significantly between themselves. For that purpose, several Mann-Whitney $U$ tests will be subsequently applied between all possible pairs of groups. Due to this fact, the Bonferroni correction of alpha values will be used first to eliminate first-order errors. The Bonferroni adjustment means to divide alpha value 0,05 by the number of tests to be performed and then to use the thus revised alpha level as a criterion defining the significance level, so that alpha value remains at a reasonable level in all tests together [15]. Here, this means a stricter alpha level of $0,05 / 3=0,017$. For each group comparison, after the Mann-Whitney $U$ test is 
performed, effect size is calculated, i .e., the strength of a relationship between variables, and estimated based on Cohen's criterion.

For the case of comparing combine speeds between the low- and medium-yield-level zones, using the MannWhitney $U$ test, the $\mathrm{Z}$ statistic for analyzed plot equals 5,65 with significance level $p=0,000$, Tab. 4 . This leads to the conclusion that there is a significant difference in average speed level between these two yield-level groups. Average rank values, Tab. 3, for low yield level are 1639,03 and for medium yield level 1831,20. This difference indicates the orientation of difference between speed levels. As in rank calculations the lowest value was assigned value 1 , so it is obvious that yield-level values for combine speeds in the medium-yield-level zone were assigned a higher rank.

Table 3 Ranks for combine speed in groups with small and middle-yield-level

\begin{tabular}{|c|c|c|c|c|}
\hline & Yield mass(dry) (binned) & $N$ & Mean rank & Sum of ranks \\
\hline \multirow{3}{*}{$\begin{array}{l}\text { D্ } \\
\text { ڤ } \\
\text { की }\end{array}$} & $\leq 3,650$ & 1728 & 1639,03 & 2832236,50 \\
\hline & $3,651 \div 4,400$ & 1742 & 1831,20 & 3189948,50 \\
\hline & Total: & 3470 & & \\
\hline
\end{tabular}

Table 4 Results of Mann-Whitney U test for combine speed in groups with small and middle-yield-level

\begin{tabular}{|l|r|}
\hline \multicolumn{1}{|c|}{$\begin{array}{c}\text { Grouping variable: } \\
\text { yield mass(dry)(binned) }\end{array}$} & \multicolumn{1}{c|}{ Speed } \\
\hline Mann-Whitney U & 1338380,500 \\
\hline Wilcoxon W & 2832236,500 \\
\hline$Z$ & $-5,650$ \\
\hline Asymp. Sig. (2-tailed) & .000 \\
\hline
\end{tabular}

Using the value of $Z$, given in the results, it is possible to calculate the approximate value of effect size:

$$
r=\frac{Z}{\sqrt{N}},
$$

where $\mathrm{N}$ is the total number of cases (observations) that occurred at 2-second intervals for the case of speed measurements during combine moving across the plot and along the corresponding pass. In statistics, effect size is the strength of a relationship between two variables in statistical population or its random samples. Effect size is calculated using descriptive statistics data that transfer the estimated value of the relationship without any conclusion on whether the evident relationship in the data reflects a true relationship in the population. This way, the impact of $r$ is a complement to inferential statistics, like $p$ value [16].

For the case of comparing combine speeds between groups of low and medium wheat yield level on the analyzed plot $(Z=-5,65$ and $N=3470)$, effect size amounts to 0,096 . This would be considered a very low impact according to Cohen's criterion [17]. In his very influential book about statistical significance, Cohen presented his impression in general about the effect levels of $r$ used in investigations to distinguish between lower and higher effect size. Cohen defined effect sizes as 'small' = about 0,1 ; 'medium' $=$ about 0,3 and 'large' $=$ from 0,5 to infinity. Since then, these values have been employed in investigations as standards for estimating the size of effects, despite Cohen's warnings of their inadequacy for general use [18]. For the case of comparison between groups of medium and high yield levels, given in Tabs. 5 and $6(Z=-7,953$ and $N=3467)$, effect size amounts to just above 'small' value, i.e. 0,135 ; which is still considered a 'small' effect size.

Table 5 Ranks for combine speed in groups with middle and large-yield-level

\begin{tabular}{|c|c|c|c|c|}
\hline & Yld mass(dry) (binned) & $N$ & Mean rank & Sum of ranks \\
\hline \multirow{3}{*}{ 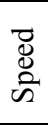 } & $3,651 \div 4,400$ & 1742 & 1868,54 & 3255002,50 \\
\hline & $4,401+$ & 1725 & 1598,13 & 2756775,50 \\
\hline & Total: & 3467 & & \\
\hline
\end{tabular}

Table 6 Results of Mann-Whitney U test for combine speed in groups with middle and large-yield-level

\begin{tabular}{|l|r|}
\hline \multicolumn{1}{|c|}{$\begin{array}{c}\text { Grouping variable: } \\
\text { yield mass(dry) (binned) }\end{array}$} & \multicolumn{1}{c|}{ Speed } \\
\hline Mann-Whitney U & 1268100,500 \\
\hline Wilcoxon W & 2756775,500 \\
\hline$Z$ & $-7,953$ \\
\hline Asymp. Sig. (2-tailed) & .000 \\
\hline
\end{tabular}

Table 7 Ranks for combine speed in groups with small and large-yield-

\begin{tabular}{|c|c|c|c|c|}
\hline \multicolumn{5}{|c|}{ level } \\
\hline & $\begin{array}{l}\text { Yld mass(dry) } \\
\text { (binned) }\end{array}$ & $\mathrm{N}$ & Mean rank & Sum of ranks \\
\hline \multirow{3}{*}{ 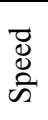 } & $\leq 3,650$ & 1728 & 1747,56 & 3019781,50 \\
\hline & $4,401+$ & 1725 & 1706,41 & 2943549,50 \\
\hline & Total: & 3453 & & \\
\hline
\end{tabular}

For comparison of combine speeds between low- and high-yield-level groups, Tabs. 7 and $8, Z$ statistic equals -
1,213, while significance level verifying this value amounts to 0,225 , so it is deduced that combine speeds between mentioned groups do not differ statistically significantly.

Table 8 Results of Mann-Whitney U test for combine speed in groups with small and large-yield-level

\begin{tabular}{|l|c|}
\hline \multicolumn{1}{|c|}{ Grouping variable: yld mass(dry) (binned) } & Speed \\
\hline Mann-Whitney U & 1454874,500 \\
\hline Wilcoxon W & 2943549,500 \\
\hline$Z$ & $-1,213$ \\
\hline Asymp. Sig. (2-tailed) & .225 \\
\hline
\end{tabular}

For the case of comparing combine speeds between all groups of barley yield levels on the analyzed plot, significance level used to calculate $Z$ statistic equals 0,000 . When speeds are compared between barley lowand medium-yield-level groups on the analyzed plot $(Z=$ $-13,055$ and $N=1395$ ) effect size amounts to 0,35 , for 
medium and high yield level $(Z=-11,051$ and $N=1392)$ effect size amounts to 0,35 , for medium and high yield level $(Z=-11,051$ and $N=1392)$ effect size is 0,296 , and for low and high yield level $(Z=-3,689$ and $N=1393)$ effect size being 0,1. According to Cohen's criterion, effect size is medium for comparison of speeds in the first two cases and small for the third case.

\section{Conclusion}

On the basis of presented analysis results a general conclusion cannot be drawn about combine speed depending on yield level of particular crops. However, it is inferred that combine speed change on the plot during harvesting depends of the crop homogeneity stand and distribution uniformity of the yield level of a particular crop on the observed plot. On the analyzed plots, the most uniform distribution of crop stand and yield level was established on the rapeseed plot, so it inferred that for significance level $p=0,102$ combine speed does not vary on the plot zones arranged into different yield-level groups. Also, on the majority of plots, the combine was noticed to have the tendency to move fastest on the medium-yield-level zones, while speed declines in the low- and high-yield-level zones. In the low-yield-level zones, lodging has been more widespread, therefore the cutting bar has to be lowered and speed reduced due to possible damages to the cutting bar. In high-yield-level zones, speed has to be reduced due to increased combine throughput and preventing 'bottlenecks' occurrence on some of the combine technological devices. The KruskalWallis $\mathrm{H}$ test and Chi-Square, respectively, the mean rank and median are certainly a powerful and reliable tools for the analysis of combine speed dependence on yield level and can be applied whenever necessary. The MannWhitney $U$ test subsequently applied for the wheat plot has shown that combine speeds within low- and highyield-level groups do not differ statistically significantly between themselves. Comparison of combine speeds between medium- and low- and high-yield-level groups, respectively, leads to the conclusion that combine speeds differ, but in small effect size, according to Cohen's criterion. The subsequent Mann-Whitney $U$ test for analyzed barley plot has shown that combine speeds within all groups differ statistically significantly, however effect size being small and medium, according to Cohen's criterion.

\section{References}

[1] Birrell, S. J.; Sudduth, K. A.; Borgelt, S. C. Comparison of sensors and techniques for crop yield mapping. // Computers and Electronics in Agriculture. 14, 2-3(1996), pp. 215-233. DOI: 10.1016/0168-1699(95)00049-6

[2] Arslan, S.; Colvin, T. S. An evaluation of the response of yield monitors and combines to varying yields. // Precision Agriculture. 3, (2002), pp. 107-122. DOI: 10.1023/A:1013887801918

[3] Fulton, J. P.; Sobolik, C. J.; Shearer, S. A.; Higgins, S. F.; Burks, T. F. Grain yield monitor flow sensor accuracy for simulated varying field slopes. // Applied Engineering in Agriculture. 25, 1(2009) pp. 15-21. DOl: $10.13031 / 2013.25425$
[4] Pierce, F. J.; Anderson, N. W.; Colvin, T. S.; Schueller, J. K.; Humburg, D. S.; McLaughlin, N. B. Yield Mapping. In The state of site-specific management for agricultural systems. // WI: ASA, CSSA and SSSA / Madison, 1997. pp. 211-243. DOI: 10.2134/1997.stateofsitespecific.c11

[5] Ryan, R.; Harry, D.; Jim, P.; Wonmo, K. A dynamic grain flow model for a mass flow yield sensor on a combine. // Precision Agriculture. 12, 5(2011), pp. 732-749. DOI: 10.1007/s11119-010-9215-0

[6] Zhou, J.; Cong, B.; Liu, C. Elimination of vibration noise from an impact-type grain mass flow sensor. // Precision Agriculture, (2014), DOI: 10.1007/s11119-014-9359-4

[7] Chung, S. O.; Sudduth, K. A.; Drummond, S. T.. Determining yield Monitoring system delay time with geostatistical and data segmentation approaches. // Transactions of the ASAE. 45, 4(2002), pp. 915-926. DOI: $10.13031 / 2013.9938$

[8] Beal, J. P.; Tian, L. F. Time shift evaluation to improve yield map quality. // Applied Engineering in Agriculture. 17, 3(2001), pp. 385-390.

[9] Simbahan, G. C.; Dobermann, A.; Ping, J. L. Screening yield monitor data improves grain yield maps. // Agronomy Journal. 96, 4(2004), pp. 1091-1102. DOl: 10.2134/agronj2004.1091

[10] Lyle, G.; Bryan, A.; Ostendorf, B. Post-processing methods to eliminate erroneous grain yield measurements: review and directions for future development. // Precision Agriculture. 15, (2014), pp. 377-402. DOI: 10.1007/s11119013-9336-3

[11] Beck, A. D.; Searcy, S. W.; Roades, J. P. Yield data filtering techniques for improved map accuracy. // Applied Engineering in Agriculture. 17, 4(2001), pp. 432.

[12] Ping, J. L.; Dobermann, A. Processing of yield map data. // Precision Agriculture. 6, 2(2005), pp. 193-212. DOI: 10.1007/s11119-005-1035-2

[13] Shearer, S. A.; Higgins, S. G.; McNeill, S. G.; Watkins, G. A.; Barnhisel, R. I.; Doyle, J. C.; Leach, J. H.; Fulton, J. P. Data filtering and correction techniques for generating yield maps from multiple combine systems. Paper No. 971034. ASAE, St Joseph, MI, USA. (1997).

[14] Significance Testing: Parametric \& Nonparametric. // Statistical Associates Publishers / Garson, G. D. Asheboro, NC, 2012. pp. 91-95.

[15] Tabachnick, B.G.; Fidell, L.S. Using multivariate statistics $\left(5^{\text {th }}\right.$ edn). Boston: Pearson Education. 1990.

[16] Ellis, P. D. The Essential Guide to Effect Sizes: An Introduction to Statistical Power, Meta-Analysis and the Interpretation of Research Results. Cambridge University Press. United Kingdom, 1960.

[17] Cohen J. W. Statistical Power Analysis for the Behavioral Sciences $\left(2^{\text {nd }}\right.$ ed. $)$. Lawrence Erlbaum Associates. Hillsdale, NJ. 1988.

[18] Lipsey, M. W.; Puzio, K.; Yun, C.; Hebert, M. A.; SteinkaFry, K.; Cole, M. W.; Roberts, M.; Anthony, K. S.; Busick, M.D. Translating the Statistical Representation of the Effects of Education Interventions Into More Readily Interpretable Forms. United States: U. S. Dept of Education, National Center for Special Education Research, Institute of Education Sciences, NCSER 2013-3000. 2012. http://ies.ed.gov/ncser/pubs/20133000/pdf/20133000.pdf

\section{Authors' addresses}

Vojislav Simonovic, Research and Teaching Assistant University of Belgrade

Faculty of Mechanical Engineering

Kraljice Marije 16

11120 Belgrade, Serbia

E-mail: vojislav@simonovic.rs 
Dr Dragan Markovic, Full Professor

University of Belgrade

Faculty of Mechanical Engineering

Kraljice Marije 16

11120 Belgrade, Serbia

E-mail: dmarkovic@mas.bg.ac.rs

Ivana Markovic, Teaching Assistant

University of Belgrade

Faculty of Mechanical Engineering

Kraljice Marije 16

11120 Belgrade, Serbia

E-mail: imarkovic@mas.bg.ac.rs

Dr Snežana Kirin, Full Professor

Innovation Center of the Faculty of Mechanical Engineering

Kraljice Marije 16

11120 Belgrade, Serbia

E-mail: skirin@mas.bg.ac. 